\title{
TO LIGHT.
}

Some time ago I had the pleasure of drawing the attention of the readers of Anglia to the unsatisfactory manner in which verbs of the $3^{\text {rd }}$ class are treated in most of those English grammers which are generally regarded as the best and most reliable.

To-day I beg the reader's attention for the verb to light. Reminding the reader of its two distinct meanings, I shall first give a synopsis of what the various grammarians say about its conjugation.

Morris. Outlines of English Accidence. p. 170. sub. 8.

"The suffix $d$ is dropped after $d, t$, the combination st, $r t$, ft, and the present, past, and passive participles have the same form, as

\section{light, light, light.}

Some of these verbs have the regular from, as lighted, quitted etc.

Turning to Kellner's new edition of the Outlines I naturally expected to find this curious mistake corrected. Nothing of the kind! Herr Kellner, who in many parts has greatly improved Morris's book, has been extremely conservative as regards the verb. (He does not e. g. give the form "dared" = "durst".)

Mason English Grammar, p. 73, gives light, lit, lit in the text, but adds in a note:

From the A. S. leohtan. The verb light or alight, 'to come down gently', is from lihtan (liht = Germ. leicht). The two verbs, however, have been confounded, and the forms lighted and lit, are used indifferently. 
Mason, A shorter English Grammar, p. 64, merely gives light, lit, lit.

Sweet. A New English Grammar. 1408: light : lit, lighted. The Consonantal preterite-form lit does not, of course, appear till light has become (loit), that is, in the $\mathrm{Mn} \mathrm{E}$ period, when it arose from imitation of bite, bit, etc. The verb alight still keeps the older consonantal inflexion, which is also used in the other verbs.

Mätzner. Grammatik I. 384.

Light, auf etwas treffen (vgl. alight dass. und herabsteigen); lit; lit, wofür sich auch light findet, wird jetzt regelmässig flektirt. Angels. lîhtan; lîhte; lîhted, levare, âlîhtan, desilire (ab equo); altengl. lighten; lighte; lighted, light, woneben liten, lyten; lit; lit (auch lizth bei Halliwell s. v.) $=$ to light on, to fall on, vorkommt. Der Infinitiv lite ist noch dialektisch im gebrauch. Das particip lit s. bei Shakespeare: You are lit into my hands (Pericl. 4. 3).

Van Tiel. English Grammar $3^{\text {rd }}$ ed. p. 62.

light lit R. lit R. (R. = regular).

Stoffel. Handleiding II. $6^{\text {th }}$ ed. p. 112. light *lit *lit.

(* denotes that the weak forms are also used)

As will be seen Morris gives two forms: the regular one in $e d$, and one found in Early Modern English, but not in use at present. The Contracted form lit he does not even mention!

Mason gives the two forms in his English Grammar, but not in the shorter Grammar. Sweet, van Tiel, and Stoffel all three clearly state that two forms are in use.

Mätzner's remark about light is rather obscure. He gives no instances of the use of 'light' = 'anzünden', and seems to consider lit as an obsolete form. Perhaps 'auch' has fallen out after 'jetzt'.

The following instances of the use of 'light' are from authors of the present century. I thought it would be suffiicient for my purpose to quote from modern writers, especially as I am collecting materials for a work on the history of the English verb, which will show the fate of the various strong, irregular weak, and anomalous verbs in the course of the centuries. Forms of 'alight' I only give from quite recent books, 
as this verb has been very fully treated in the New English Dictionary where the curious reader will find ample information.

\section{Pret. lighted. $19^{\text {th }}$ cent.}

Who .. first lighted a martyr fire in Scotland. Morley. Sketch of English Literature. 268.

His old eyes lighted up. Newcomes 772.

The wax-candles that lighted the faded sea-green draperies. Braddon, Vixen 252. Seaside.

He lighted his candle. ib. 286.

He lighted a lamp to show him the way. Fortunes of Nigel. 352. Then he - lighted his reading lamp. A. Swan. A Foolish Marriage. 69 .

So he lighted a cigarette. Ouida. Tower of Taddeo. 28.

And the same fires lighted water, and bridge, and dome, and palace. ib. 124 .

She lighted a lamp. ib. 133.

They - - lighted candles. ib. 191.

We refilled our glasses, lighted our pipes. Jerome. Three men in a boat. 11 .

Harris cocked his legs on the table and lighted a cigar. ib. 47. They - lighted their pipes, ib. 117.

So he lighted the lamp and got out the chess-board. ib. 142. The smoky horn lantern which alone lighted that end of the stable. Stanley Weyman, Man in Black. 39.

She lighted a candle. Martin Chuzzlewit. 210.

She lighted the rush-light. ib. 211.

His face lighted up. Edna Lyall. Won by waiting. Seaside. 47. His eye lighted up with professional ambition. Dr. Jekyll and Mr. Hyde. 41. Tauchnitz.

The sunlight - - lighted up his white hair. Hardy Norseman. 135.

His face lighted up. ib. 166.

The bright northern light - - lighted up his own (face). Newcomes. 653.

The logs lighted up that luxurious hearth. Vixen 9. Lisbeth went in again quickly and lighted a candle. Adam Bede, 283. 
Her bright calm face lighted up with pleasure. Dav. Copperfield. XVI.

I noticed how her eye lighted on me. ib. XXXIV.

She - set one candle at the head, and another at the feet of the body, and lighted both. Guy Mannering. 250. Black $\&$ Sons.

Sir Geoffrey lighted a cigarette. Maarten Maartens. Sir Geoffrey's Theory. Graphic, Christmas Number 1894, 12.

$\mathrm{He}$ - lighted his German meerschaum. Ernest Maltravers. 12.

Mrs. Templeton made no answer, but lighted her candle. ib. 110.

He lighted his pipe. M. E. Francis, A Daughter of the Soil. IX. They lighted their candles in the little parlour. Esther Waters, by George Moore, 237. Melbourne Series.

He locked himself in, and lighted a lamp. Astor. Red Dwarf of Rabenstein. Pall Mall M. 6/95.

They lighted their fire under the lea of one such buttress. The Woman who Did, 235. Tauchnitz.

His eyes lighted on Tess Durbeyfield. Thomas Hardy, Tess of the Turbervilles. I, 26. Tauchnitz.

The landlord lighted a lantern. Shiel: Ben. New Budget. $20 / 6$ '95.

Sherlock Holmes rose and lighted his pipe. Conan Doyle. Study in Scarlet. I, 2.

I lighted a cigar and puffed at it to steady my nerves. ib. II, 6 . There lighted on his lap a bunch of red anemones. W. H. Wallock. Between Flesh and spirit. Pall Mall Mag. 10/95.

She lighted the candle to see what it was. Tess. II. 49.

He relighted his pipe. S. J. Duncan, His Honour and a Lady. XV.

As soon as they reached the room where the candles were lighted she looked at his face. Tess. II. 238.

One lowered gas-burner lighted the room. Up in Arms. VII. The yellow luminosity upon the horizon lighted the ridge.

Tess. I. 109.

Then he - lighted a bit of tinder with a practised hand. Marion Crawford, Greifenstein I. 20.

Greifenstein - relighted his pipe. ib. I. 198.

He lighted the candles upon the dressing-table. ib. 204.

Women sang to him and lighted his pipefuls. The story of

Miss Pi. Harper's Monthly. Jan. 1896. 
His face lighted into a beaming smile. Arthur Paterson, For Freedom's Sake, XII.

Danby's face lighted at the word. C. Granville, The Sluicers of Backwash Creek; Pall Mall Mag. 5/96.

But he - walked in, and lighted his candle. Christmas Carol I. The two men lighted cigars and cigarettes. H. A. Bryden, the

Story of a Tusk. Pall Mall Mag. 6/96.

The gleam of a lamp - lighted him to the foot of the staircase.

Blanche Loftus Tottenham, A Venetian Love Story, VI.

The young man's face lighted up. ib. X.

Sir Robert lighted her candle for her. Benson, Dodo, 256.

So I lighted it and smoked it. A. Griffiths, Sister Sencilla.

Pall Mall Mag. 7/96.

The lieutenant lighted gracefully the expensive cigarette russe.

The Fish of M. Quissard. Harper's Monthly, 11/96.

He returned to his chair and deliberately lighted a cigar.

Stevenson, St. Ives, III.

\section{Pret. lit. $19^{\text {th }}$ century.}

His smile lit up the dark sunburned face. Braddon, Vixen, 49. Seaside.

The ruddy light - - lit up her pale cheeks. ib. 77.

The moon - - lit up the blackness. Rider Haggard, She. 45. One faint, flying ray of light lit upon the face. ib. 46.

The knife - lit upon its handle. ib. 92.

A bright, sudden smile lit up Carlo's sad face. Lyall, $\cdot$ Knight Errant. 54. Oxford Series.

He lit a cigar. ib. 171.

It lit all the air above it. Hall Caine, She's all the world to me. 13.

She duly and promptly lit her lantern. ib. 66 .

He struck his matches and lit the gorse. ib. 72 .

The light lit up the entire castle. ib. 121.

The old man lit his pipe. Hall Caine. Shadow of a crime. 47. Here he lit a pipe. ib. 187.

A bright red glow - lit up the air about it. ib. 237.

Rotha lit a candle. ib. 278.

It - - lit up the blue eyelids. ib. 282.

The bleared sun lit up his lifted face. ib. 298.

Then he lit a cigarette. A. Swan. A Foolish Marriage. 71. 
A flash and sparkle of colour that lit up the sombre bench. Weyman. The Man in black. Tauchn. 236.

The bailiff looked in, and lit his pipe. Tower of Taddeo. 198. Then he lit a cigarette. ib. 256.

Madame tripped up the grand staircase and under the great lamp which lit it and the hall. Man in Black. 153.

The strange scene which the many lights lit up. ib. 170.

He lit a cigar. Bret Harte. Cressy. 37. Tauchn.

The fireglow lit up the picture of the squire. Vixen. 11.

For some rays - lit up her pale red hair. Adam Bede. (Blackwood), 61.

He took a cigar out of his case and lit it. Trollope. Is he Popenjoy? 180.

And the three of us sat down and lit our pipes. Rider Haggard. King Solomon's Mines, 15.

So we lit our pipes. ib. 169.

And when I lit a match - - ib. 289.

Hastily I lit the last remaining match. ib. 296.

While he lit the weed. Ernest Maltravers, 16.

The gleam of the fire in the ingle-nook lit up the massivebeamed ceiling. G. B. Burgin, Within the Gates. Pall Mall Mag. 1/95.

A sunbeam, bolder than the rest, stole in and lit up the face of the little royal sleeper. Princess Crystal's Quest, by Dor. Stephens. Pall Mall M. 1/95.

Bob Sefton took up his pipe, and lit it afresh. A Daughter of the Soil. IX.

Rachel stirred the stove, and lit the lamp. Hall Caine, Mahdi 4. By ill-chance his eye lit - on our masks. A Gentleman of France, II, 198.

Old John lit his pipe and led the way. Esther Waters, 237. Early as was the hour, Whyte and I lit cheroots. Gordon Casserly, "A Griffin" after "Pig". Pall Mall Mag. 579, 1895.

Our repast ended, we lit our cheroots. ib. 585.

They lit their fires at the edge of some dark lake. Ole Lardav's Son-in-law. Pall Mall Mag. 4, 1895.

And then he lit his pipe. A. Beringer. The Princess Bamboo.

Pall Mall M. 5/95.

He lit his pipe. ib. 
They covered the poles with layers of bark - and then int a fire. Marquis of Lorne, Quee. Pall Mall Mag. 1895.

I lit the candles. New Budget. 18/4/95 p. 11.

The sun lit up their figures. Th. Hardy. Tess. I. 20.

I dragged over a chair and lit the candles. Egerton Castle, Light of Scarthey. XIII.

I lit a candle hastily. Hichen. A Re-incarnation. Pall Mall Mag. 8/95.

I went to my den, lit a cigar, and walked uneasily up and down. ib.

I lit a second cigar. ib.

I lit the candle and looked at her. ib.

Yes, until I lit the candle. ib.

The smile that lit up his steel-blue eyes. Light of Scarthey. XVII.

The glory of joy that lit up eye and lip left no room for any other impression. ib. XXIII.

Hope lit up her face. ib.

D'Urberville mechanically lit a cigar. Tess I, 111.

She lit a candle and went to a second and a third bed. Tess I. 136.

She had placed candles upon the tables, and now they lit them. ib. II. 25.

He - speedily lit a fire. ib. II. 52.

So I lit my pipe. Foot of Gautama. Pall Mall Mag. Nov. '95. Our crew lit a fire near one of the idols. ib.

The light still remaining in the sky lit up her face. Tess II. 108. She lit her lamp to get up. ib. 124.

- Jenny lit a candle. A Night and Morning. New Budget. 5/9 1895.

A pitiful white smile lit her face as she spoke. Tess II. 261. Then, his meal finished, he lit a pipe. Trilby I, 14.

She made herself a cigarette, and lit it. ib. 29.

Little Billee got the bacchanalian into his room and lit his candle for him. ib. 205.

Then he filled himself another pipe and lit it. ib. 244.

A smile which lit up his face. Mrs. Oliphant. Carità. I. 129. He - lit a cigar with the strong determination not to give way to such nonsense. Greifenstein, I. 95. 
At last the latter took out a black South American cigar and lit it. ib. 198.

He lit a taper and prepared to help him up the stairs. ib. 258. Rex lit the lamp in the small room. ib. 258.

At last he rose and lit a candle. ib. II. 191.

He lit a cigar. Trilby II. 120.

The man on the doorstep lit a match. A. E. Rowlands, A - Beginning and an End. Pall Mall Mag. 2/96.

Taffy filled his glass, and gave him a cigar, and lit one himself. Trilby II, 267.

He lit a cigar. ib. II, 120.

A smile that lit up his sombre face. A. Paterson, For Freedom's Sake, I.

Some of the men lit the petroleum lamps. W. Besant, The City of Refuge, III.

Robert's face lit up. For Freedom's Sake, XVIII.

The faces of the younger men lit up as if tonched by fire. ib. III.

A flash of lightning - intensely vivid, lit up the White House. ib. IV.

The liquor brought and the door closed, Captain Howlett lit a cigar. ib. XIV.

Watching the flashes which lit up - the farm buildings. City of Refuge, III.

The flashes of lightning lit up the farm-buildings. ib.

I lit my candle. M. Howard, The stone chamber of Taverndale House. Pall Mall Mag. 6/96.

The light which lit up the radiant jewels. ib.

I lit the candles. ib.

It lit up the dark corners of the building. H. A. Bryden, The Story of a Tusk. Pall Mall Mag. 6/96.

Jack fidgeted, lit a match and blew it out again. Benson, Dodo, 30.

Dodo lit a cigarette. ib. 46 .

Those he had picked up for himself, before he lit on Silver. Stevenson, Treasure Island, 103.

He lit his candle. Vachell, Hannibal Hoke, Phil. D., M. D. Pall Mall Mag. 9/96.

The professor of physical culture lit another cigar. ib. 
Frere - - re-lit his corncob pipe. Cutcliffe Hyne. The Orange-growers. Pall Mall Mag. 9/96.

Even the most vacuous faces lit up. Walter Besant. The City of Refuge, XIV.

He deliberately lit another cigarette. Croker, Beyond the Pale. I.

He searched for a lamp and lit it. Venetian Love Story, IX. Paolo stared speechless, watching him as he lit it. ib. X.

The old man lit a long Virginia. ib. XIII.

Then he fumbled for his pipe and lit it. ib. XVII.

Paolo - lit a candle. ib. XIX.

He turned suddenly from him and lit the lamp. ib. XXXIII He lit the little lamp. H. Crackanthorpe, Wreckage, 216; 223. He struck a match, and clumsily lit it again. ib. 227.

The man whose crimes and loves and achievements lit up the first years of the cinque cento. Jack Sheppard tells the Story. Pall Mall Mag. 12/96.

Adolphus Hornblower who quite lately lit a bonfire in his college quadrangle. Roundabout Readings, Punch, 2, 1, 97. She trimmed and lit the lamp. Weyman, House on the Wall. She - lit a spill of wood. ib.

Then Barty - rolled himself a cigarette and lit it. du Maurier. The Martian. III.

And his pipe was brought and filled, and he lit it. ib. II.

$$
\text { Part. Participle: lighted. } 1^{\text {th }} \text { century. }
$$

The lamps had long ago ceased to be lighted. Lyall. Won by Waiting 39. Seaside.

The candles and lamps were lighted. Vixen 80.

Long rows of tall windows brilliantly lighted. ib. 96 .

In the dimly-lighted room. ib. 118.

The night-lamp was lighted. ib. 133.

The way the house is lighted and heated. ib. 176.

Dimly lighted by flickering oil-lamps. ib. 235 .

Several more had now been lighted. She 77.

A picture of that gayly lighted ballroom. Knight Errant, 157. The conservatory - was dimly lighted. Vixen 286.

When he had taken her candle - and lighted it - ib. 286. Where a wood fire had been newly lighted. ib. 312.

The stage - - was lighted by lamps. Shadow of a crime. 164 . 
The place was lighted at night by two lamps. ib. 218 .

No candle was now lighted. ib. 280.

The dingily lighted little hall. A. Swan. A Foolish Marriage. 51. I have had a fire lighted. Emma Marshall. Benvenuta. 15.

The room was very dimly lighted. ib. 166.

The staircase was dark as night, being lighted only by small slits. Ouida. Tower of Taddeo. 28.

Her father's face uas lighted up. ib. 56.

Crescets, filled with lighted oil. ib. 126.

Eyes - lighted with the lambent flame of high intelligence. ib. 187.

The candles which the men had lighted. ib. 192.

The lamps were lighted. ib. 198.

There are few things more beautiful than is the Arno lighted thus. ib. 213.

Lighted by the pale stars. Jerome. Three Men in a boat. 20. Then the big pipes are filled and lighted. ib. 20.

Emily says that papa does not like the gas lighted in the afternoon. ib. 154 .

When the pipes are lighted. ib. 165.

Towns ought to be lighted by electricity. Idle Thoughts of an Idle Fellow. 63.

Whenever they passed before a lighted booth. Man in black. 28. To stand gaping at the lighted windows. ib. 35 .

The inner chamber, which was lighted by six candles - ib. 93.

Two wax candles stood lighted on the table. Jane Eyre. Tauchn. I, 168.

A large, square hall, dimly lighted from above. Won by Waiting, 64.

All lighted up as if for a procession. Ir. Jekyll and Mr. Hyde. 14. Tauchn.

A lamp was set lighted on the chimney shelf. ib. 46.

The hall - was brightly lighted up. ib. 65.

Which - was lighted from above. ib. 75.

The way became lighted up from end to end. ib. 113.

The fires were lighted on a level space. Stevenson. Master of Ballantrae. 267. Tauchn.

The dimly lighted night-nursery. Lyall. Hardy Norseman. 59. A big, brightly lighted hall. ib. 133. 
A newly-lighted candle. Vixen. 3.

So the stables were lighted by lanterns. ib. 6 .

A well-lighted room. Trollope. Is he Popenjoy? 175.

But dimly lighted from above. King Salomon's Mines. 267.

Not nearly so well lighted. ib, 266.

The fire in the best room not being lighted. David Copperfield. Ch. I.

I picture my small self in the dimly-lighted rooms. ib. V.

Manvers stumbled up the rickety, badly lighted stairs. E. F.

Benson. Love's Apostate. Pall Mall Mag. 1894. p. 377.

Streets - unpaved, unlighted and uncleaned. W. W. Astor, Under the Black Flag. Pall Mall Mag. 1894, 619.

It was small - lighted at night by a single swinging lamp. ib. 627.

A tall figure - carrying the lighted candle in his hand. Mr. Potter of Texas, 17.

The scene before him - lighted up - by the rising sun of Egypt. ib. 39.

All lighted up by a sunny brightness. ib. 121.

A lighted taper upon the table. ib. 227.

The brightly lighted station. ib. 240 .

A dim view of the room within, lighted fitfully by the fire. Ern. Maltravers. 8.

Maltravers, meanwhile, had gone in and lighted his meerschaum. ib. 13.

Raising the lighted torch in his left hand. Princess Crystal's Quest. Pall Mall Mag.

And together they went upstairs, and bent, with a lighted candle, over a child's little cot. E. Hepworth Dixon, A Scribbler's Comedy. Pall Mall M. 2;95.

Many carried lighted torches. Hall Caine, Mahdi, 17.

I - - felt my way to the staircase, which was entirely unlighted. A Gentleman of France. 98.

She put a lighted match to the twigs. Daughter of the Soil, XIX. He led the way through the dark and windowless house, lighted - by the dim purple radiance. M. P. Thiel, Huguenin's Wife. Pall Mall Mag. 569, 1895.

Long, furling, growling rollers that are grey at their sluggish base and emerald-lighted at their curvetting crest. Light of Scarthey, by Egerton Castle. I. 
The wide chambers - lighted only by narrow watching loopholes. ib.

A dreary scene lighted by the dull light of a lantern. W. R. H. Trowbridge, 'In the World ye shall have Tribulation'.

And when I had laghted on it (i. e. Truth) there - I went away from Girton again. Woman who Did. 32.

That a man should have arrived at the ripe age of thirty and not yet have lighted upon the elect lady - is in itself a strong prof. ib. 38 .

Miss Landal received an early order from her brother to have a fire lighted. Light of Scarthey. XII.

The room was brightly lighted. Red Dwarf of Rabenstein.

The street-lamps, just lighted, blinked through the yellow mist. New Budget. July 11, 1895.

I could not have lighted upon a better man. Light of Scarthey. XVII.

The little room, now lighted by the fitful rays of a swinging lamp. ib. XXIII.

Captain Jack seized a lighted lantern. ib. XXIV.

It was lighted at the time. Conan Doyle. A Study in Scarlet. I. 3. If it was lighted this corner would be the brightest. ib.

The spot where the fire had been lighted. ib. II. 5.

The beacon had just been lighted by René. Light of Scarthey. XXVIII.

His pallid face was lighted by a smile. Psychological Experiment. New Budget. June 27, 1895.

The girl's lifted face, lighted by and beautiful in spite of its scorn. High winds. Francis Prevost. Pall Mall Mag. Oct. '9j.

A small room, dimly lighted by a cheap kerosene lamp. S. Levett Yeats, Foot of Gautama. Pall Mall Mag. Nov. 95.

I found myself in a large, plainly furnished but brilliantly lighted hall. Lord Frnest Hamilton, Chess Club. Pall Mall Mag. 12/'95.

The verandah was very broad and high, and softly lighted. His Honour and a Lady. XIV.

They went along the deserted street, lighted by an oil lamp. Tess II. 272.

And then a stroll on the crowded, well-lighted boulevards. - Trilby, I. 50. 
He (Napoleon) could never look at a lighted candle with composure. Literary World. 22/11, 1895.

Alone in a small bedroom with chintz curtains and a lighted candle. ib. 209.

Little Phoebe Pyncheon would at once have lighted up the whole scene. Hawthorne. The House of the seven Gables. 194. The vacant boxes and the yawning pit were brilliantly lighted. Greifenstein. I, 68.

The room - was luxurious, large, warm and softly lighted. ib. I. 208.

Trophies - lighted up occasionably by the sudden flare of the logs. ib. I. 210.

The place was lighted by a corona of gas-jets. ib. I, 158.

The dim unlighted extremity of the room. Astor, Brabantio's Love. Pall Mall Mag. 2/96.

Nevertheless, it is a noteworthy fact that a woman far back in the Middle Ages should have lighted upon the idea. Fortnightly 3/96. Plays of Hroswitha.

When I had lighted my Minghetti cigar, I was able to reply. W. L. Alden, With Romeo in Mantua. Pall Mall Mag. 4/96. An adjournment was made to the verandah, and cigars were lighted. For Freedom's Sake, IV.

Lamps were lighted in the drawing-room. ib. IV.

Robert was roused from his reverie by the flare of a lighted lamp. ib. V.

The place was lighted up. ib. V.

Half a dozen gas-lamps out of the street wouldn't have lighted the entry too well. Christmas Carol I.

After the candles were lighted. The three old Sisters and the old Beau, by M. E. Wilkins. Harper's Monthly, 854/96.

The pleasant ruby-lighted dining-room. The Story of a Tusk. Having lighted a cigarette. ib.

'Possibly', I thought, 'one of my men has lighted the fire for my benefit. Astor, The fate of Miss Tralee's Emerald. Pall Mall Mag. 1/97.

Pesach - - followed with - - a piece of lighted candle. Zangwill, Children of the Ghetto. 20.

The shade-trees - were shown up like electric-lighted streets. Cutcliffe Hyne, Wolf's Donkeymen. Pall Mall Mag. 8/96: 
Men with lighted flambeaux. M. Anderson, L. Tracy, Chadni Bhai, Pall Mall Mag. 8/96.

One of the men left the log-house, and presently returned with a lighted brand. Stevenson, Treasure Island. 223.

Council and jury resumed their pipes, and the judge, having lighted his, proceeded to address the jury. H. A. Hering, An unrecorded Trial. Pall Mall Mag. 10/96.

There was a curious barn-like modern aisle, lighted by pointed windows. Croker, Beyond the Pale. XVII.

The chandelier was lighted. Astor, Jack Sheppard tells the Story. Pall Mall Mag. 12/96.

The unlighted cigarette fell from his hand. ib.

Carryng their lighted torches. Quiller Couch, From a Cornish Window.

I was - lighted across the garden. Stevenson, St. Ives, IX. He emerged into the lighted Piazza. Venetian Love Story. XXXIV.

The jeweller had left his brilliantly lighted shop. ib. XXVIII. Up the gas-lighted Champs Elysées. Du Maurier, The Martian II

Past Participle: lit. $19^{\text {th }}$ century.

The whole of their minds might be lit up again. W. Besant. The Inner House. 236. Tauchn.

It was lit by long narrow windows. ib. 128.

The room was lit up. ib. 179.

Lit up with loving admiration. F. Montgomery. Fisherman's Daughter. 138. T.

The fires were lit there. Newcomes 770 .

The dim fire-lit room. Vixen. 80.

The sunlit sky. ib. 177.

The low moon-lit hills. ib. 187.

The sunlit sky. ib. 206.

Lamplit windows. ib. 213.

The lamplit table. ib. 220 .

A vast world of sun-lit water. ib. 235.

Having first lit our pipes. Rider Haggard, She. 77.

A city, lit up here and there. ib. 111.

This great lamp-lit apartment. ib. 125.

The place was softly lit with lamps. ib. 130 .

The stage is lit. ib. 193.

Anglia. N F. VII. 
The fire that had lit the dancing. ib. 198.

The vast moonlit courts. ib. 233.

The starlit garden. Lyall. Knight Errant. 27.

A column of vapor lit $u p$ by the fierce glare. ib. 27 .

The hot, lamplit drawingroom. ib. 72.

A sweet, bright, lovelit smile. ib. 94 .

Dimly lit by the young moon. Vixen, 247.

Sun-lit fields. ib. 302.

The sunlit ripples of a summer sea. She's all the world to me. Hall Caine. 50. Seaside.

Her lantern must be lit for the crew's sake. ib. 69 .

The fire yonder was lit to warn them. ib. 93.

The church windows were lit up. ib. 111.

The line of wild sea that was lit up. ib. 117.

Her radiant face was lit up. Hall Caine. Shadow of a Crime. 40. Fires were lit. ib. 162, 180.

In which there was lit a small but bright fire. Fortunes of Nigel. 122.

When the gas was lit. A. Swan. A Foolish Marriage, 54. This moonlit casement. Tower of Taddeo. 74.

Below her stretched the moonlit and firelit river. ib. 122.

The Hills, lit here and there with bonfires. ib. 122.

He could not now lay down unlit the slow match. ib. 221.

The lamplit and moonlit streets. ib. 226.

The gas-lit streets. Three Men in a Boat. 77.

The chill blasts whistle down dingy streets, and shriek round flaring, gaslit corners. Idle Thoughts of an Idle Fellow. 63. A splendid apartment - lit from the roof. Man in Black. 155. The hall was not dark, nor yet was it lit. Jane Eyre. I. 164. Brilliantly lit by the full moon. Stevenson. Dr. Jekyll and Mr. Hyde. 38.

The quiet, moonlit street. Hardy Norseman 244.

His feelings were lit up for him. Adam Bede. 114.

The moonlit fields. ib. 135.

The lamps were already lit. ib. 242.

When the steward had - - lit the lamp. King Solomon's

Mines. 15.

Having first lit a lamp. ib. 168.

He saw each spot an angel silvershod

Had lit upon; O'Shaughnessy, Daughter of Herodias. 
You may well say that, exclaimed Cicely, her pretty face lit up with glad surprise. J. Payn. A Prince of the Blood. I, 271. Tauch.

It was lit by a skylight. E. F. Benson. Love's Apostate. Pall Mall Mag. 1894. p. 377.

Then he - scurried down the moon-lit stairs. Maarten Maartens. Sir Geoffrey's Theory. 13. Christmas Number of the Graphic. 1894.

In the hush of the star-lit sky. ib. 13.

His dreamy study, whose windows opened wide on the sun-lit gambols of the heir. ib. 12.

My pipe was lit. Q. Bishop of Eucalyptus. Pall Mall Mag. 1894, 572.

Many a breezy canter did he have over those sunlit slopes. M. E. Francis, A Daughter of the Soil. I.

Crossing the sunlit space between, he caught sight of a figure that he recognized. ib. VI.

It was a bare room, lit with one window. Moore, Esther Waters. 5.

Having kindled a charcoal fire in a brasier and lit enough candles to give a pleasant light. ib. 33. Mr. Potter of Texas.

Percy Lincoln, who has lit the end of his cigar. ib. 129.

The moonlit abyss of Plato. Ernest Maltravers. 15.

-Before her were the flowers, and the starlit lawn. ib. 19.

Upon the moonlit lawn. ib. 130.

Glad when the lamp was lit. Daughter of the soil, XIX.

The heads - looked against the dim-lit sky like a set of nigger minstrels. Marquis of Lorne, Qwee, III. Pall Mall Mag. 1895.

The distant sunlit cone of Mount Baker. ib. III.

The little hands she laid upon them to draw them into the dim-lit library were hot as fire. Light of Scarthey. IV.

The star-lit everning. Astor. The Red Dwarf of Rabenstein. Pall Mall Mag. 6;95.

Her little copper-coloured face was lit with two great black eyes. L. Hereward, The first white man in Pine Town. Pall Mall Mag. July 1895.

As soon as he had re-lit a cigar. Tess. I. 92.

Tess's moonlit person. ib. I. 104. 
Eyes fixed upon the wide space of sunlit road. S. J. Duncan.

His Honour and a Lady. Pall Mall Mag. 1895-6. I.

The skipping rabbits on a moonlit warren. Tess. I. 124 .

A soft, yellow gleam - giving them an elfish, moonlit aspect.

Tess. I. 200.

The dim-lit recesses. Light of Scarthey. XXIX.

Blurring all the sunlit vision. ib. XXVI.

The ashes under the grate were lit by the fire vertically. Tess. II, 35.

Behind those sunlit windows yonder. Light of Scarthey, XXXV. In the sunlit haze before I saw the Don. S. Levett Yeats. Foot of Gautama. Pall Mall Mag. Nov. 1895.

The blackness was again lit up. ib.

I shall get the house swept out, and fires lit. Tess. II. 220. The mysterious population of the distant moonlit woods. Lost Hearts. Pall Mall Mag. 12/95.

A delicate piquant face, lit up by bright dark eyes. Up in Arms. VIII.

The three big lamps were lit. Trilby. I. 210.

He was the first to volunteer a song when the pipes and cigars were lit. ib. 213.

The lurid glow which a moment earlier had lit up every wall. Greifenstein. I. 244.

They were upon a moonlit lawn in summer. ib. II. 166.

When all the lamps are lit in the shops and streets. Trilby. II. 141.

The Sexton had lit the rushlight. Washington Irving, Dolf Heyliger.

When all the lamps are lit in the shops and streets. Trilby II, 141.

I saw a dark figure glide past the moonlit road. S. L. Yeats, Under the Achilles. Pall Mall Mag. 3/96.

Just now, however, they (faces) were universally lit up by eagerness after food. City of Refuge, III.

That phantom artistically draped and limelit by a poet's imagination. Without Prejudice, Pall Mall Mag. 4/96.

The still sunlit road. L. Granville. The Sluicers of Backwash Creek. Pall Mall Mag. 5/96.

Traversing the long gallery, which was now lit. Stone Chamber of Taverndale House. Pall Mall Mag. 6/96. 
My hostess - having lit my candles, wished me good night. ib. The whole terrace below me was lit up. ib.

The moonlit terrace below. ib.

His face, lit up by the red flames, has lost the sullen misery of the morning. H. A. Bryden, The Story of a Tusk. Pall Mall Mag. 6/96.

Ever recurring peeps of sunlit slopes. Biscombe Gardner. Schlangenbad. Pall Mall Mag. 9/96.

I had your fire lit. Benson, Dodo 97.

In a dim-lit way he finds consolation in that. ib. 133.

It was a soft grey texture, which Dodo said looked like a sunlit mist. ib. 161.

When one - looked over a moonlit valley. Quiller Couch, From a Cornish window. Pall Mall Mag. 1/97.

The long, leafless, moonlit avenue. Stevenson. Treasure Island, 53.

And then he bade them get the fire lit. ib. 249 .

They had lit a fire. ib. 254.

The Judge, whose grave eyes rested upon the sunlit lawn outside. Hornung, A Bride from the Bush, 9.

To where the sunlit river was a silver band. ib. 72 .

One little glimpse of the sunlit bush. ib. 126.

The half-lit room. ib. 135, 140.

There was some rowing on the sunlit river. ib. 143.

A face lit up with news. ib. 244.

Motionless against the starlit sky. Blanche Loftus Tottenham.

A Venetian Love Story, XIII.

She turned (her eyes) from the sunlit lagune. ib. X.

The lamp in Jacopo Dinelli's shop was already lit. ib. XVI. The edges of the cloud-bank were lit for an instant. ib. XVII. It shot up against the star-lit sky. Ib. XXII.

The place was lit with lamps. ib. XXV.

The deep starlit blue of the sky. ib. XXVIlI.

Dino had lit his pipe. ib. XXXIII.

A World of dark chaos, luridly lit by the flames of burning hamlets. Stanley Weyman, The House on the Wall.

All through that lamp-lit hour and a half. The Martian II. The cold lamp-lit ninety minutes' preparation. ib. II. Just as the lamps are being lit. ib. III. 
She looked altogether beautiful, her face lit up in a delicate flush of excitement. Crackanthorpe, Wreckage, 4.

Her face lit up to excited radiancy. ib. 89.

I found myself in an immense room, brilliantly lit by electricity. Roundabout Readings. Punch 19, 9, 96.

The gloom of the cold, unlit garret. Zangwill, Children of the Ghetto 114.

The warm voluptuous, starlit night. Astor, The Fate of Miss

Tralee's Emerald. Pall Mall Mag. 1/97.

Three times it has been lit for me. Harold Frederic, The Wooing of Teige. Pall Mall Mag. 11/96.

Alight. Preterite. $19^{\text {th }}$ cent.

She alighted from the van. Tess. I. 47.

D'Urberville alighted, and lifted her down. ib. 113.

They were nowhere to be seen when I alighted. Chess. Club. Pall Mall Mag. 12/95.

Scanning the one or two passengers that alighted on the forsaken little platforms. ib.

Not a solitary soul alighted. ib.

He alighted, and walked beside her. Up in Arms. XIII.

Fordham alighted, and approached his would-be benefactor. ib. XXII.

He stood staring at the moth as it aligthed there. Venetian Love Story, $\mathrm{X}$.

\section{Alight. Past Participle. $19^{\text {th }}$ cent.}

A solitary traveller had alighted. Baggage Smasher. Pall Mall Mag. 10/95.

The skim of a bird which has not quite alighted. Tess. I. 249. A scarlet oozing appeared where her blow had alighted. ib. II. 187.

Molly had alighted and was toiling. Light of Scarthey. XXXV.1

From these instances it is evident that:

1. Both forms are in common use among the best authors of the present day.

2. Lit is much used, especially as a form of the preterite.

1 It will be noticed that nearly all the quotations are from proseworks. 
3. The past participle lit is particularly common in combinations such as: gas-, moon-, sun-, star-lit.

4. In the same author we find both forms used promiscuously.

5. Of light $=$ alight, the pret. lighted occurs three times, and the pret. lit four times; the past participle lighted four times, the form lit, once.

To recapitulate:

The pret. lighted occurs 58 times

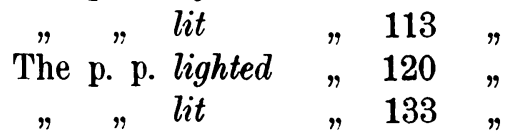

which seems to show that lit is much more common in the pret. and slightly more common in the p. p. than lighted.

Our English grammars should therefore explicitly state that both forms are in general use.

From the instances given in the Oxf. Dict. it would appear that the form alit is very rare. I have nowhere found this form, which - according to the Oxf. Dict. - occurs only in the $19^{\text {th }}$ century.

Almeloo, 1897.

A. E. H. Swaen. 